\title{
Spatial synchrony of wader populations in inland lakes of the Iberian Peninsula
}

Received: 27 May 2016/ Accepted: 13 October 2016

(C) The Ecological Society of Japan 2016

\begin{abstract}
Spatial synchronization refers to similarity in temporal variations between spatially separated populations. Three mechanisms have been associated with the spatial synchrony of populations: Moran effect, dispersal and trophic interactions. In this study, we explored the degree of spatial synchrony of three wader species populations (Pied Avocet, Black-winged Stilt and Kentish Plover) using monthly estimates of their abundance in inland lakes of the Iberian Peninsula. The effect of several types of wetland variables (structural, hydroperiod and landscape) on spatial synchronization was explored. Groups of lakes with significant synchronization were identified for all three species. The lakes with wastewater input presented longer hydroperiods than those that did not receive these effluents, and this factor was positively related to the spatial synchrony of the Pied Avocet and Kentish Plover populations. The distance between lakes (used as an indicator of the dispersal effect on synchronization) was significant only in Pied Avocet. No structural or landscape variables were related to spatial synchronization in any species. It was impossible to identify any variable related to the spatial synchronization of Black-winged Stilt abundance as a
\end{abstract}

M. S. S. Gonçalves $(\bowtie) \cdot$ J. A. Gil-Delgado

Departamento de Microbiologia y Ecología, Universidad de

Valencia, Valencia, Spain

E-mail: mayconsanyvan@gmail.com

R. U. Gosálvez

Departamento de Geografía y Ordenación del Territorio,

Universidad de Castilla-La Mancha, Ciudad Real, Spain

\section{G. López-Iborra}

Departamento de Ecología/IMEM Ramon Margalef, Universidad de Alicante, Alicante, Spain

\section{A. Ponz}

Departamento de Didática de las Ciencias Experimentales, Facultad de Ciencias Sociales y Humanas, Universidad de Zaragoza, Saragossa, Spain

\section{A. Velasco}

Departamento de Ciencias Ambientales, Universidad de CastillaLa Mancha, Ciudad Real, Spain possible result of the high ecological plasticity of this species. Our data provides the first evidence for mechanisms that act on the spatial synchronizing of wader populations in temporary continental lakes in central Spain, and show that the hydroperiod of lakes acts as an important factor in the spatial synchronization of aquatic species and that its effect is mediated by the reception of urban wastewater.

Keywords Similarity temporal - Spatial dynamic

Wetlands · Hydroperiod · Wastewater

\section{Introduction}

Understanding variations of abundance in space and time has been one of the major goals in ecology (Cazelles and Stone 2003; Liebhold et al. 2004). Notably, population dynamics has received plenty of attention since the models presented by Moran (1953). Moran (1953) described statistical methods to observe the temporal patterns of the Canadian lynx, and proposed a formal ecological mechanism to analyze spatial population synchrony on large geographic scales. Conceptually, spatial synchrony of populations refers to the temporal similarity of abundance (or any other characteristic of a population) between sites separated spatially (Liebhold et al. 2004). In other words, regardless of the size of the local population, two or more sites are synchronized if the curves of abundance of both sites are coupled. Spatial synchrony is one of the most important patterns in metapopulations dynamics, being observed at different scales (local, regional and global), as well as in many species groups (Holyoak and Lawler 1996; Thrall et al. 2001; Post and Forchhammer 2002; Trenham et al. 2003; Liu et al. 2009; Batchelder et al. 2012; Kvasnes et al. 2013).

In general, spatial synchrony of abundance has been associated to three ecological processes, which can act independently or in combination: dispersal of individuals, environmental conditions and trophic interactions

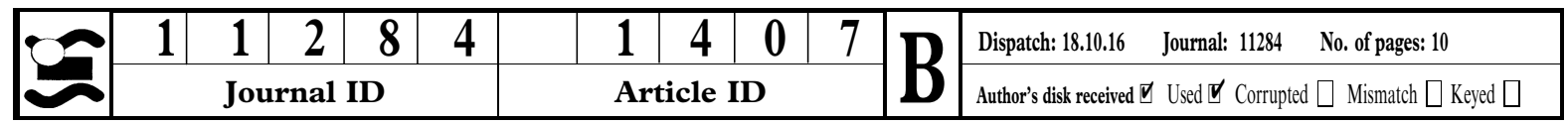




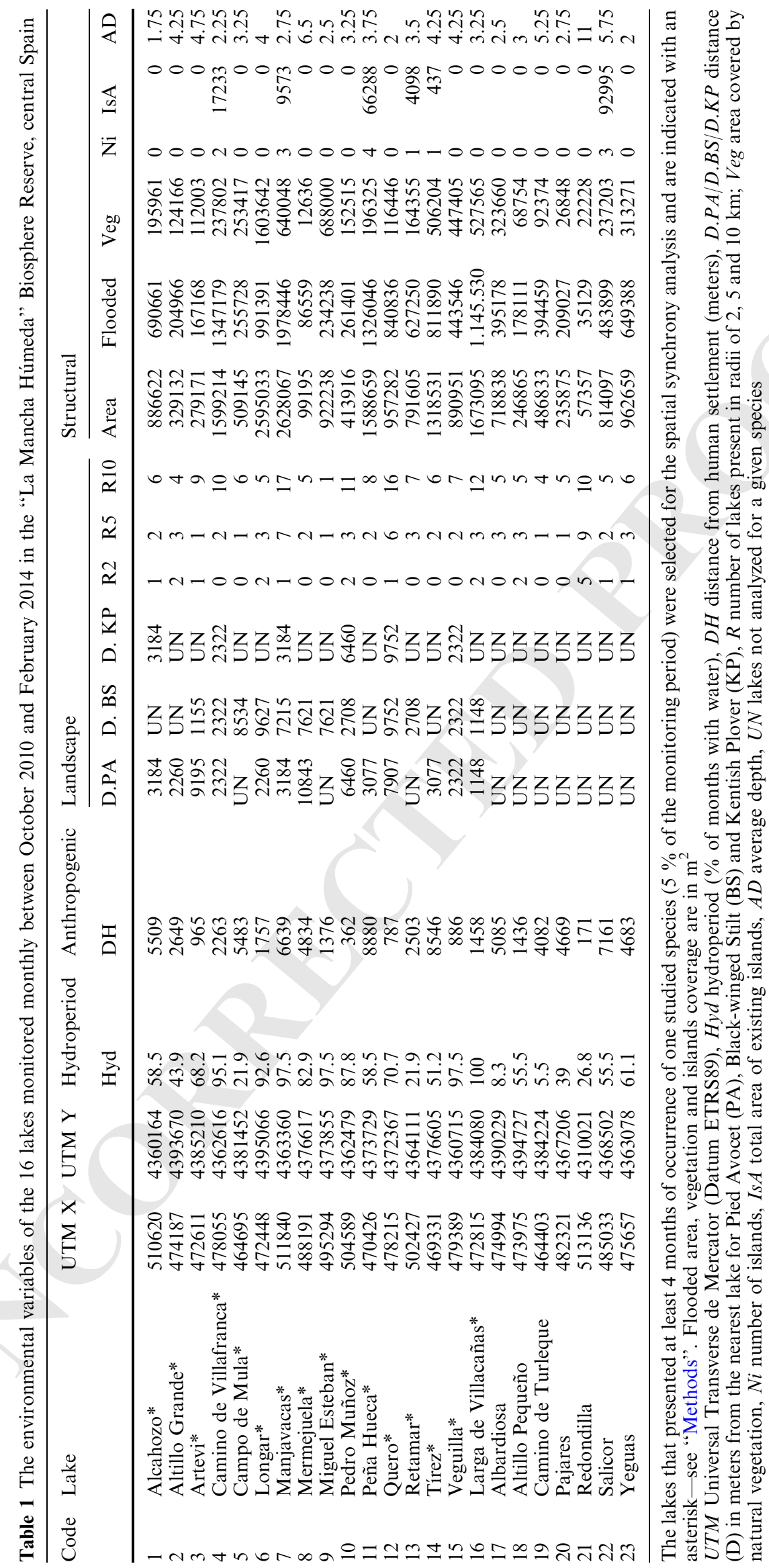

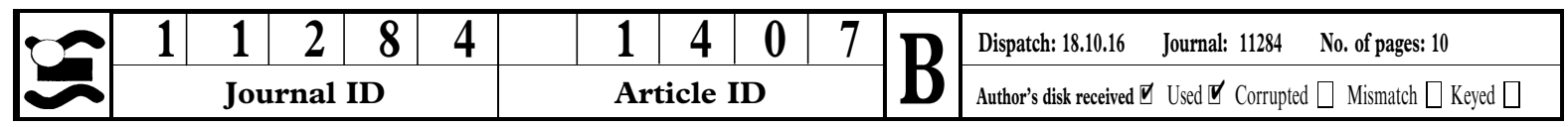




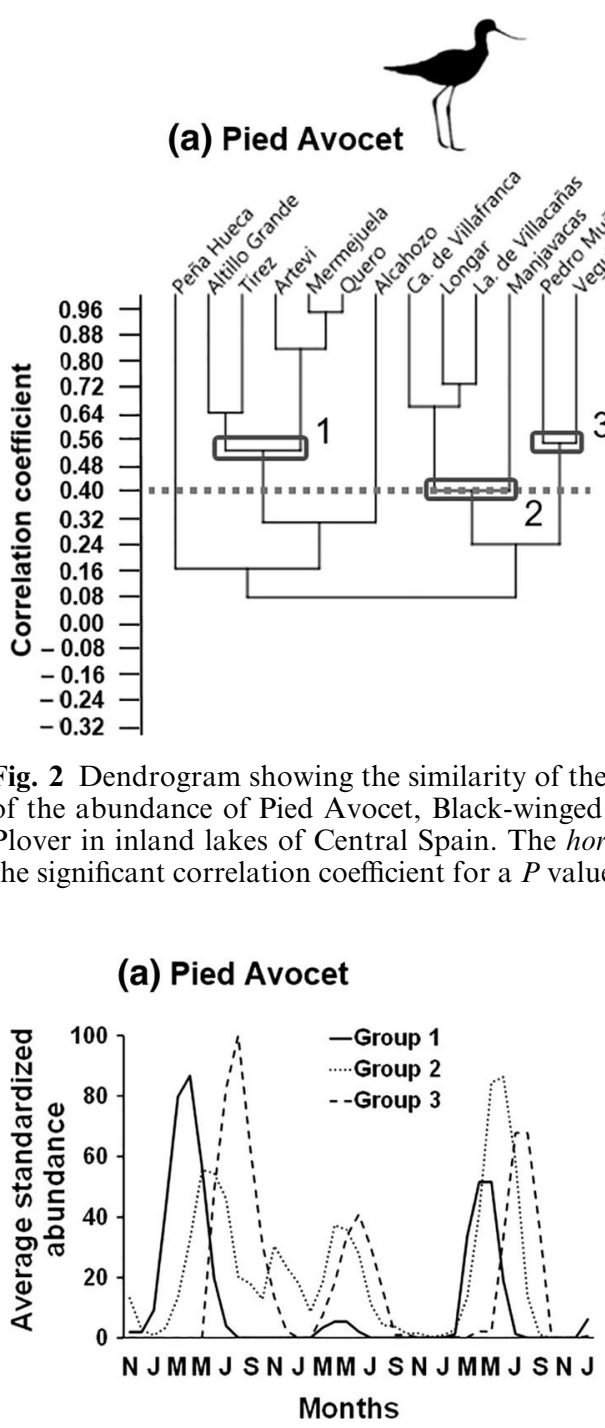

Fig. 3 Average temporal pattern of each group of lakes identified by the dendrograms of each species (Fig. 2). To generate these graphs we standardized the monthly abundance values of each lake by dividing them by the maximum abundance observed in that lake

\section{Results}

Groups of lakes with significant synchronization were identified for the three species. A few lakes showed temporal patterns which did not correlate to the others (Fig. 2). The groups of lakes also presented a coincident pattern of fluctuation between years - the groups with previous and later peaks of abundance maintained the same periodicity in years 1 and 3 , but with distinct variation in study year 2 (Fig. 3).

Pied Avocet. Three groups of lakes with significant temporal similarity were identified (Figs. 2, 3). Group 1 (Quero, Mermejuela, Artevi, Altillo Grande and Tírez) showed earlier peaks of abundance, which occurred in late winter and early spring (Figs. 3, 4a). Group 2 presented later and more long-lasting periods of high abundance, which extended from late spring to late (b) Black-winged Stilt

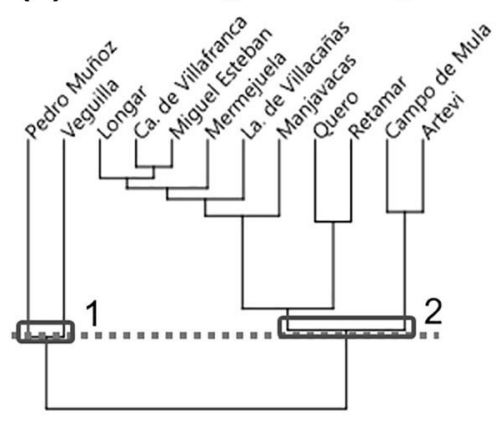

(c) Kentish Plover

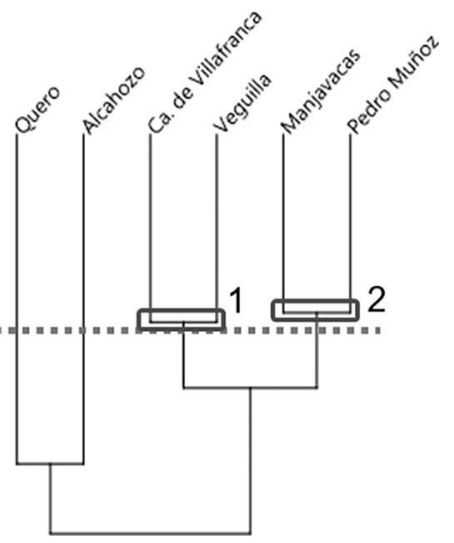

threshold to define groups, identified by numbered frames at the base of the branching shared within each group. The names of the lakes are located over the dendrogram branches

(c) Kentish Plover

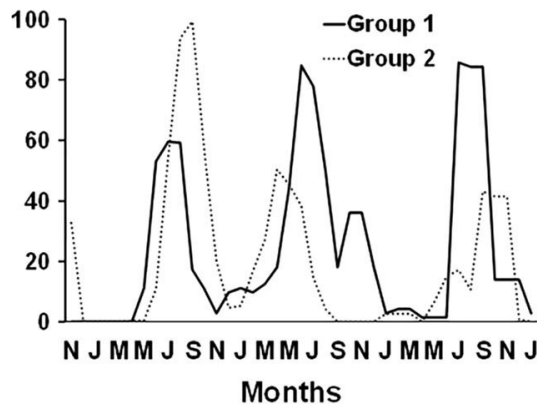

and then multiplying by 100 . In this way, we obtained a series that ranged between 0 and 100 for each lake, and we then averaged the series of all the lakes of the group. Months are labelled alternately starting in November (N) 2010

summer. In this group, Manjavacas lake had large numbers of Pied Avocets during the 2012 breeding season (year 2), when the abundance in the rest of the lakes sharply dropped. Group 3 (Veguilla and Pedro Muñoz) presented abundance peaks later (late summer-early fall).

Black-winged Stilt. Two groups which included all the analyzed lakes were identified (Figs. 2, 3). Group 1 (Veguilla and Pedro Muñoz) showed later peaks, which occurred in late summer-early fall (Fig. 3). The lakes in Group 2 presented abundance peaks between late spring and midsummer (Figs. 3, 4b).

Kentish Plover. Two groups with two lakes each were formed, but the similarity between lakes in the same group was relatively low (Figs. 3, 4c). Lakes Alcahozo and Quero showed particular temporal patterns (Fig. 4 c).

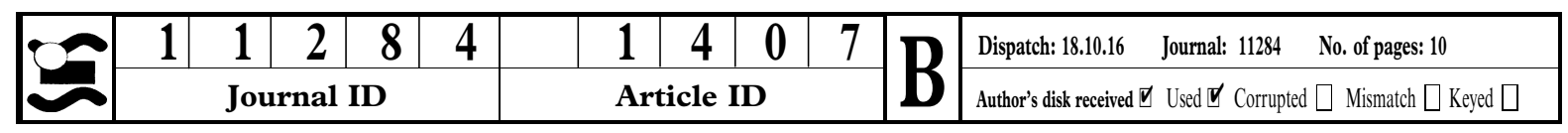


(a) Pied Avocet

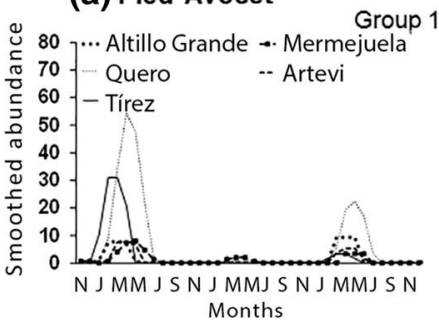

(b) Black-winged Stilt
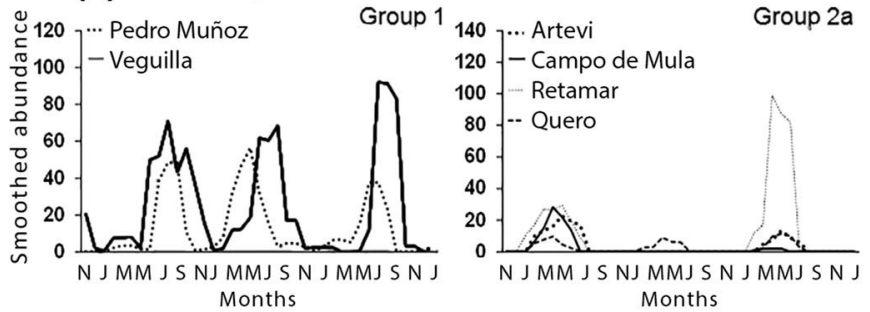

(c) Kentish Plover
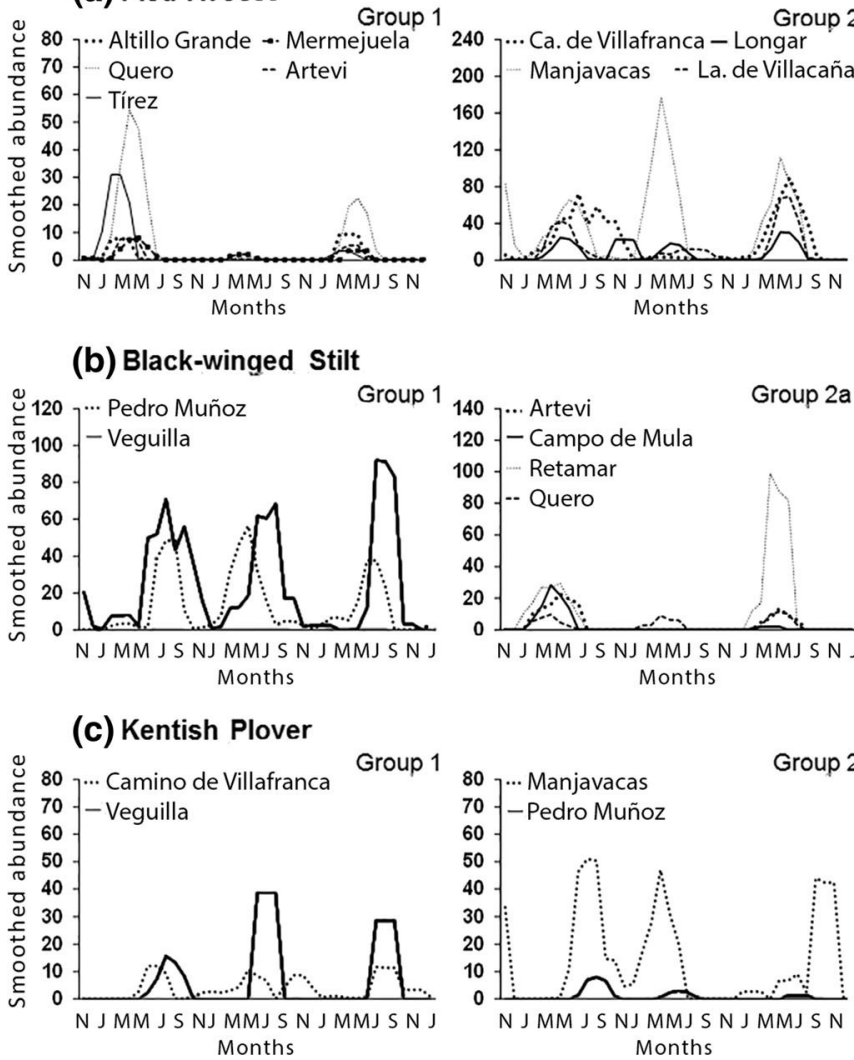

Months

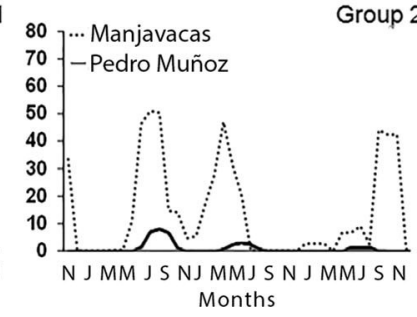

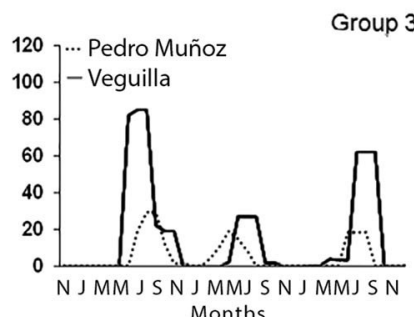

Months

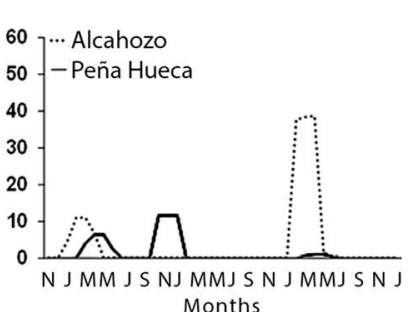

Months

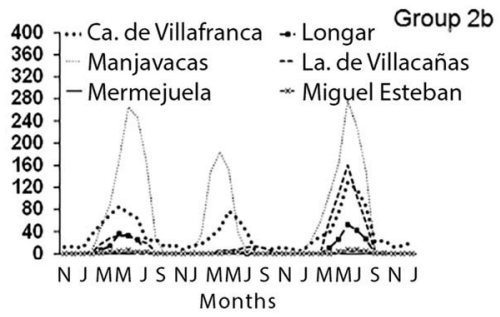

Fig. 4 Temporal variation (moving averages) of the abundance of the three wader species in the studied lakes. Groups of lakes were defined from the dendrograms in Fig. 2. For Black-winged Stilt, lakes in Group 2 are shown in two graphs for better visualization of their temporal patterns (Groups 2a and 2b). Panels without
Of the 12 environmental variables explored, only hydroperiod and distance between the lakes were related to the spatial synchrony of some species (Table 2). No correlation was observed between these environmental variables (Mantel Test, $\mathrm{r}=0.048 ; P=0.260$ ).

For Pied Avocet, the environmental variables that correlated to spatial synchrony were hydroperiod (Mantel Test, $\mathrm{r}=0.380 ; P=0.004$ ) and distance between lakes (Mantel Test, $\mathrm{r}=0.250 ; P=0.046$ ). In Kentish Plover, the hydroperiod was the only variable that was related to the temporal patterns of the lakes (Mantel Test, $\mathrm{r}=0.710 ; P=0.043$ ). None of the environmental variables was related to the high spatial synchrony levels observed for Black-winged Stilt (Table 2).

The lakes that received wastewater presented longer hydroperiods than those that did not receive such effluents $(U=4.00 ; P<0.001)$ (Fig. 5). Seven of the eight lakes with no input of wastewater had marked seasonality of presence of water and were flooded between 22 and $68 \%$ of the months (except lake Camino de Villafranca) (Fig. 5). The eight lakes that received wastewater presented water for most of the study period $(71-100 \%)$.

\section{Discussion}

Our results show that the degree of spatial synchrony of the populations of Pied Avocet, Black-winged Stilt and Kentish Plover in inland lakes of Iberian Peninsula is significant. However, the patterns of synchrony of the three species showed different levels of responses to the set of variables explored. The spatial synchrony of Pied Avocet and Kentish Plover is affected by the hydroperiod of lakes, which in turn is altered by wastewater input.

Spatial synchrony and hydroperiod effect

In partial agreement to our first hypothesis, the hydroperiod effect was important on temporal patterns of two of the three species: Pied Avocet and Kentish Plover. For Pied Avocet, we observed the formation of three groups of spatially synchronized lakes: groups with

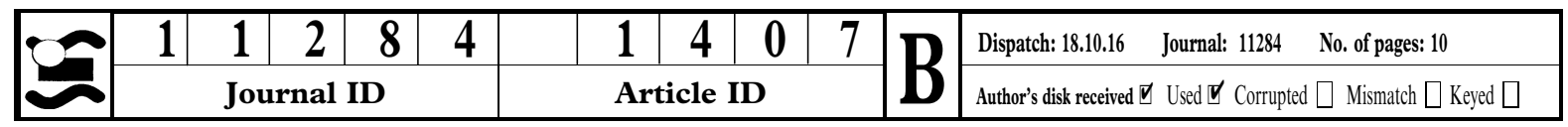


Table 2 Results of the Mantel tests run to evaluate the correlation of environmental variables with the spatial synchrony of populations

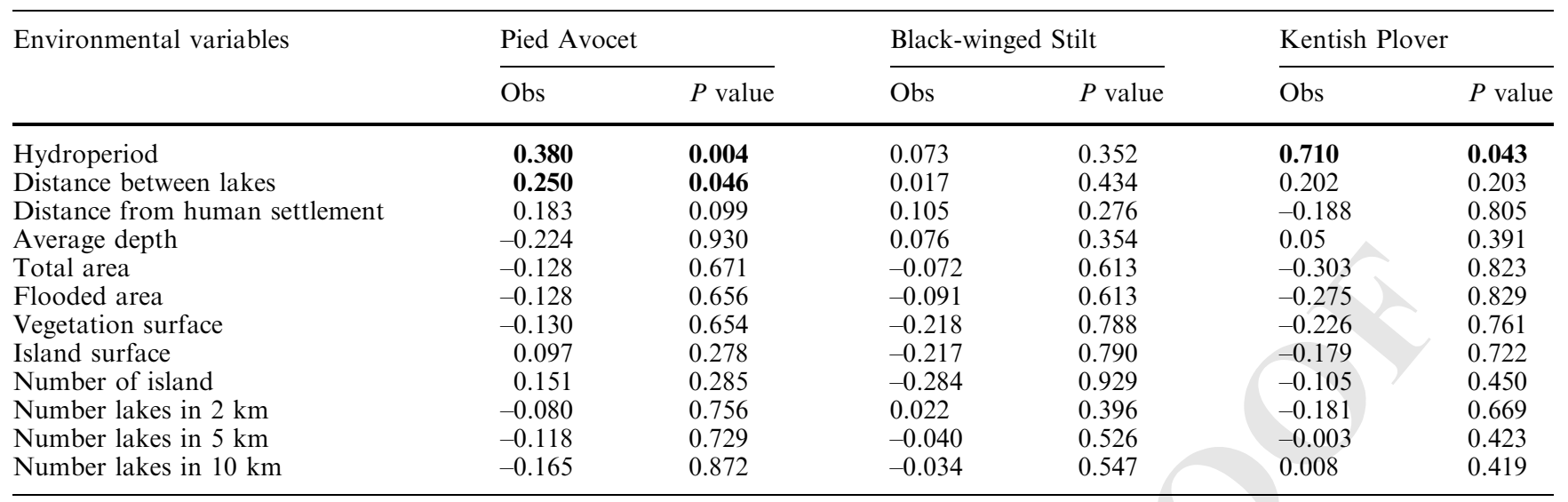

Bold values are statistically significant tests for a $P$ value less than 0.05

earlier peaks of abundance, intermediate peaks and later peaks. The group of lakes with earlier peaks (beginning of spring) were also characterized by shorter hydroperiods (flooded between 22 and $68 \%$ of the months) and they did not receive wastewater (except Lake Quero). Unlike the lakes that received wastewater, unaltered lakes tend to rapidly dry in the spring and summer. Temporal variation of abundance depends not only on movements for tracking the spatial changes in resources availability (Borkhataria et al. 2012), but also on largescale migratory movements and reproduction output (Sirot and Touzalin 2014). Therefore, the passing of migrants in spring could cause a detectable early peak of abundance in lakes with shorter hydroperiod since in these lakes the number of individuals that stay for breeding is relatively low and diminishes quickly as they dry, while in lakes with longer hydroperiod a more numerous breeding populations remains for longer time.

On other hand, later abundance peaks occurred synchronously in the same lakes for Pied Avocet and Blackwinged Stilt (Lakes Veguilla and Pedro Muñoz). Lakes that receive effluents from urban wastewater treatment plants present inappropriate bio-physical conditions in late summer (Vidal et al. 2013; Anza et al. 2014), but display high organic productivity (Anza et al. 2014) and are attractive sites to waterbirds during breeding periods (Gosálvez et al. 2012). Unlike the other lakes that receive wastewater and present long hydroperiods, Veguilla and Pedro Muñoz have large concentration of emerging macrophytes on its edges, and few flat shallow areas for foraging of waders in the breeding season. However, during the summer, while other areas are dry or nearly dry, Veguilla and Pedro Muñoz gradually expose extensive mudflats in their central area that attract many waders. Consequently, the decrease of the abundance of individuals after the mid-summer in some lakes with longer hydroperiods (e.g. Manjavacas, Larga de Villafranca, Miguel Esteban, Longar and Mermejuela) and the coincident increase at Pedro Muñoz and Veguilla lakes is possibly the result of structural differences between the wetlands, which has significant effects on foraging habitat availability.

In the case of Kentish Plover the lakes that presented significant temporal correlation were those with longer hydroperiods, where this species presented peaks of abundance in midsummer, although with more variability in Manjavacas and Pedro Muñoz. On the contrary, in the lakes that usually dry in midsummer (Quero and Alcahozo), Kentish Plover showed abundance peaks in winter or spring. These alternating patterns of Kentish Plover abundance in these groups of lakes suggest that part of the population of this species could switch between wetlands depending of the fluctuating conditions in them.

The varying effect of hydroperiod on the spatial synchrony of the study species might be explained by differences in their natural history, especially related to their foraging strategy and habitat selection (NtiamoaBaidu et al. 1998; Granadeiro et al. 2006; Kuwae 2007). Black-winged Stilt tend to forage solitary in shallower waters than Pied Avocet, which frequently forage in flocks (Ntiamoa-Baidu et al. 1998). Therefore, as the studied lakes are shallow, the gradual loss of water during the summer may reduce faster the habitat quality for Pied Avocet, favoring the synchronization of lakes with similar hydroperiods. Kentish Plover forage in shores or shallow water (Kosztolányi et al. 2007; Hanane 2011) and their feeding efficiency decreases as saltmarshes dry, forcing parents to move with broods to lakeshores (Kosztolányi et al. 2006). This behavior could explain that, like Pied Avocet, their temporal pattern is affected by hydroperiod. The lack of effect of hydroperiod on the spatial synchrony of Black-winged Stilt, together with its capacity for living in a wider variety of aquatic environments (Hortas et al. 2012), would explain the more similar temporal pattern between lakes in this species as shown by the high correlations between lakes.

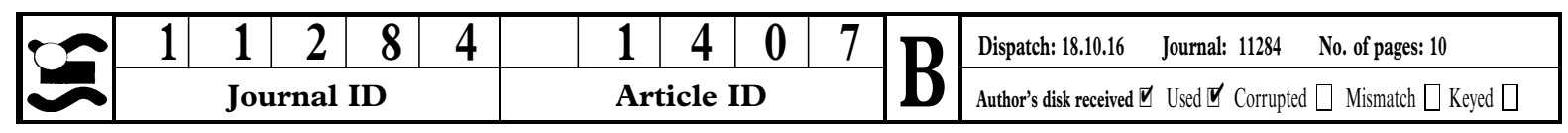




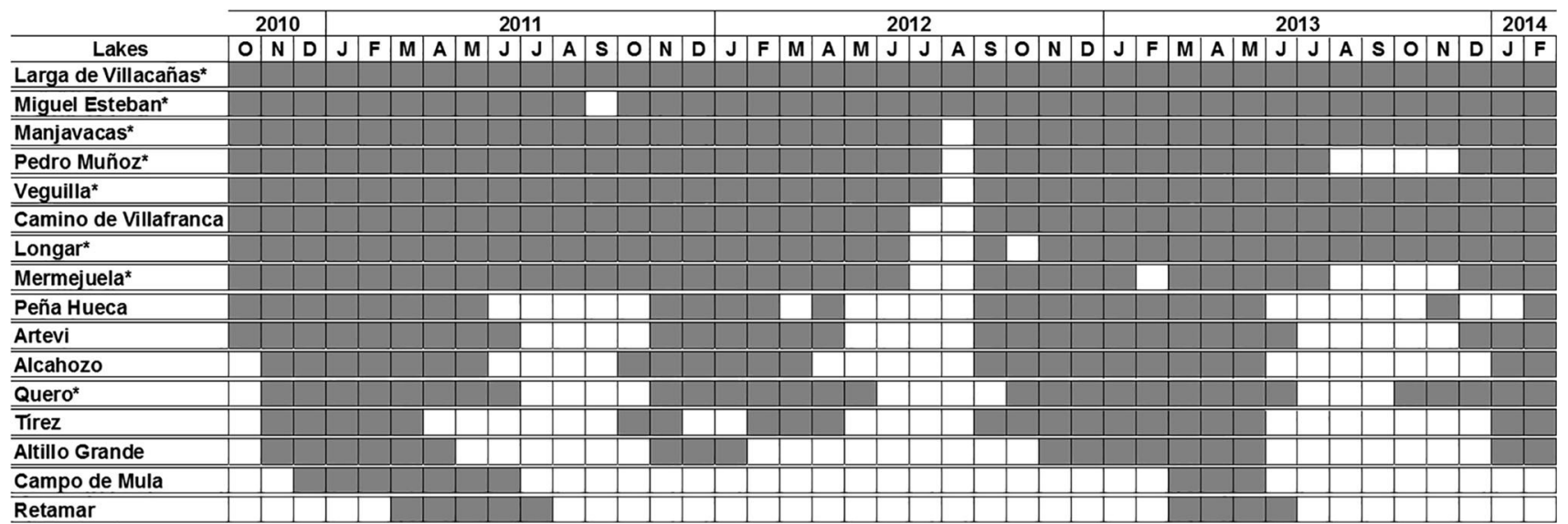

Fig. 5 Hydroperiod of the 16 lakes selected for the analysis. Gray cells identify months with presence of water between October 2010 and February 2014. The lakes marked with an asterisk received wastewater

For the three species, we also observed that the abundance peaks of the groups of lakes showed constant periodicity in study years 1 and 3, with an asynchrony found in study year 2. As many theoretical and empirical studies have observed, identifying patterns and processes of temporal population dynamics is not an easy task and it is necessary to consider also the effect of random events, like environmental and demographic stochasticity (Brown et al. 1995; Ives and Klopfer 1997). Even the lakes that received wastewater can dry in summer if the water accumulated in winter was low. This appeared to be the case of most of our study lakes in the summer of 2012, when all the sites (except Miguel Esteban and Larga de Villacañas) were completely dry in August. According to the weather data of the province of Toledo (Spanish Meteorology Agency - AEMET), the rain accumulated in previous fall and winter was lower in $2012(109.1 \mathrm{~mm})$ than in $2011(236.1 \mathrm{~mm})$ and 2013 $(283 \mathrm{~mm})$. In parallel, for all three species we also observed a similarity in the temporal patterns of the groups of lakes between 2011 and 2013, with distinct variation found in 2011. Specifically, the groups of lakes in 2012 tend to present earlier abundance peaks than in the other two years. This difference may be a direct response to variations in rainfall since it is known that changes in hydrological conditions affect not only food availability (Bancroft et al. 2002; Roshier et al. 2002), but also movements of individuals during the breeding periods (Borkhataria et al. 2012).

Many studies have found that different factors may act together in the formation of synchronous patterns (Ranta et al. 1999; Powney et al. 2011; Eberhart-Phillips et al. 2015; Mortelliti et al. 2015). For instance, hydrological disturbance and dispersal were important mechanisms driving spatio-temporal patterns of Everglades fish populations (Ruetz et al. 2005). In our study, at least in one species (Pied Avocet) the distance between lakes and hydroperiod seemed to act together to cause the spatial synchronization of populations. Ranta et al. (1999) demonstrated that correlated extrinsic distur- bances are capable of synchronizing population dynamics in combination with the distance effect. In our case, as in the system studied by Ruetz et al. (2005), the hydroperiod was not correlated to the distance among sites and seems to promote spatial synchrony independently from dispersal.

Distance effect and other variables

Although dispersal mechanisms have been commonly related to the spatial synchrony of many species, including birds (Koenig 1998, 2001), detecting and understanding the relationship between distance and synchronization of populations is not always easy. This is because when motivated by dispersion, spatial synchrony depends on many factors, including the dispersal ability of individuals (Sutcliffe et al. 1996), the degree of functional connectivity between patches (Powney et al. 2011), the spatial scale (Paradis et al. 1999) and presence of environmental disturbances (Ranta et al. 1999). Functional connectivity refers to the environmental permeability of a given landscape, which facilitates or hinders the movement of individuals between patches and/or fragments (Goodwin and Fahrig 2002, Powney et al. 2011). In our study, we analyzed a set of landscape variables, such as distance from human settlements, distance between lakes and number of lakes within three increasing radii as indicators of the functional connectivity of lakes (Goodwin and Fahrig 2002). We also evaluated a set of structural habitat variables and their relationship to the observed temporal patterns. None of these variables was associated with the spatial synchrony of the studied species, except distance between lakes in Pied Avocet. Given the high dispersal capacity of these species (Hötker 2002; SEO/BirdLife 2016a, b) and the relative proximity of the lakes (maximum distance $94 \mathrm{~km}$ ), the distance seems not to be affecting the spatial synchrony of Black-winged Stilt and Kentish Plover. Only in the case of Pied Avocet we detect an effect of

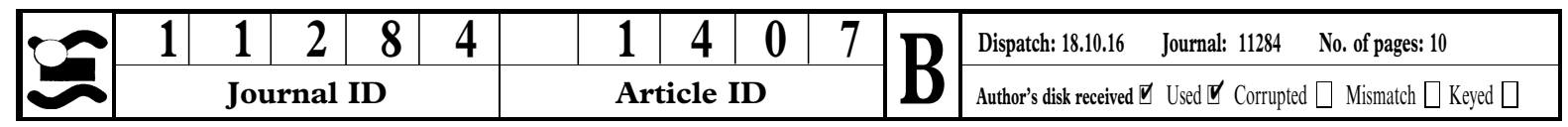


distance between lakes on their spatial synchrony, that was weaker than hydroperiod effect. Overall, the absence of effect of landscape and habitat variables is related to the ecology of the analyzed species, which are able to occupy sites scattered in extensively altered landscapes (Hortas et al. 2012; Hortas 2012a, b).

\section{Conclusions}

For more than three decades, inland lakes of the Iberian Peninsula have undergone significant changes in water regimes as a result of channelled surface water, overexploitation of aquifers and wastewater input. The monthly census approach conducted herein allowed us to detect how hydrological disturbance (wastewater input) affects the spatial synchrony of populations and generates diverse temporal patterns of abundance variation. Our data provide the first insights into the mechanisms that drive spatial synchrony in temporary inland lakes. Further research on this topic in central Spain wetlands, that present one of the most altered hydric functioning in the Iberian Peninsula, will help to design water management strategies that improve habitat quality for wader species.

Acknowledgments This study forms part of the doctoral thesis of $\mathrm{M}$ S. S. G. and was supported by a grant from CAPES - Coordenação de Aperfeiçoamento de Pessoal de Nível Superior, Brazil). The present work was performed within the Project ECOLAKE "Ecological patterns in endorheic lakes: the keys to their conservation, CGL2012-38909" (Universidad de Valencia), funded by the Spanish Ministry of Economy and Competitiveness, and by the European Union through the European Fund for Regional Development (FEDER) "One way to make Europe". We thank Priscila dos Santos Pons for support in the review of the data tables, and Carmen Vives for support in some field trips. Special thanks go to Carlos Rochera, Christian Andretti, Carla Olmo, Jeferson Vizentin-Bugoni and Máximo Florín, who made important contributions to this manuscript.

\section{References}

Anderson MJ, Walsh DCI (2013) PERMANOVA, ANOSIM, and the Mantel test in the face of heterogeneous dispersions: what null hypothesis are you testing? Ecol Monograph 83:557-574. doi: $10.1890 / 12-2010.1$

Anza I, Vidal MD, Laguna C, Díaz-Sánchez S, Sánchez S, Chicote A, Florín M, Mateo R (2014) Risk factors for avian botulism outbreaks in wetlands receiving effluents from urban wastewater treatment plants: eutrophication and bacterial pathogens. Appl Environ Microbiol 80:4251-4259. doi:10.1128/AEM. 00949-14

Bancroft GT, Gawlik DE, Rutchey K (2002) Distribution of wading birds relative to vegetation and water depths in the northern Everglades of Florida, USA. Waterbirds 25:265-277. doi:10.1675/1524-4695(2002)025[0265:DOWBRT]2.0.CO;2

Batchelder HP, Mackas DL, O'Brien TD (2012) Spatial-temporal scales of synchrony in marine zooplankton biomass and abundance patterns: a world-wide comparison. Prog Oceanog 97-100:15-30. doi:10.1016/j.pocean.2011.11.010

Bellamy PE, Rothery P, Hinsley SA (2003) Synchrony of woodland bird populations: the effect of landscape structure. Ecography 26:338-348. doi:10.1034/j.1600-0587.2003.03457.x
Bjørnstad ON, Ims RA, Lambin X (1999) Spatial population dynamics: analyzing patterns and processes of population synchronicity. Trends Ecol Evolut 14:427-432. doi: 10.1016/S0169-5347(99)01677-8

Borkhataria RR, Frederick PC, Keller RA, Collazo JA (2012) Temporal variation in local wetland hydrology influences postdispersal survival of juvenile Wood Storks (Mycteria americana). Auk 129:517-528. doi:10.1525/auk.2012.11244

Brown JH, Mehlman DW, Stevens GC (1995) Spatial variation in abundance. Ecology 76:2028-2043. doi:10.2307/1941678

Cazelles B, Stone L (2003) Detection of imperfect population synchrony in an uncertain world. J Anim Ecol 72:953-968. doi: 10.1046/j.1365-2656.2003.00763.x

Eberhart-Phillips L, Hudgens BR, Colwell MA (2015) Spatial synchrony of a threatened shorebird: regional roles of climate, dispersal and management. Bird Conserv Int. CJO 2015. doi: $10.1017 /$ S0959270914000379

Florín M, Montes C (1999) Functional analysis and restoration of Mediterranean lagunas in the Mancha Húmeda Biosphere Reserve (Central Spain). Aquat Conserv Mar Freshw Ecosyst 9:97-109. doi:10.1002/(SICI)1099-0755(199901/02)9:1 < 97:AID$\mathrm{AQC} 329>3.0 . \mathrm{CO} ; 2-\mathrm{F}$

Florín M, Montes C, Rueda F (1993) Origin, hydrologic functioning and mor-phometric characteristics of small, shallow, semiarid lakes (Lagunas) in La Mancha, central Spain. Wetlands 13:247-259. doi:10.1007/BF03161291

Goodwin BJ, Fahrig L (2002) How does landscape structure influence landscape connectivity? Oikos 99:552-570. doi: 10.1034/j.1600-0706.2002.11824.x

Gosálvez R, Gil-Delgado JA, Vives-Ferrándiz C, Sánchez G, Florín M (2012) Seguimiento de aves acuáticas amenazadas en lagunas de la Reserva de la Biosfera de La Mancha Húmeda (España Central). Polígonos, Revista de Geografía 22:89-122. doi:10.18002/pol.v0i22.101 (in Spanish)

Granadeiro JP, Dias MP, Martins RC, Palmeirim JM (2006) Variation in numbers and behaviour of waders during the tidal cycle: implications for the use of estuarine sediment flats. Acta Oecol 29:293-300. doi:10.1016/j.actao.2005.11.008

Hammer Ø, Harper DAT, Ryan PD (2001) PAST: Palaeontological Statistics Software Package for education and analysis, ver. 3.04. Palaeontol Electr 4:9

Hanane S (2011) Breeding ecology of Kentish Plovers Charadrius alexandrinus in rocky and sandy habitats of north-west Morocco (North Africa). Ostrich 82:217-223. doi: 10.2989/00306525.2011.616681

Haynes KJ, Bjørnstad ON, Allstadt AJ, Liebhold AM (2013) Geographical variation in the spatial synchrony of a forestdefoliating insect: isolation of environmental and spatial drivers. Proc R Soc B Biol Sci 280:20130112. doi:10.1098/rspb. 2012.2373

Holyoak M, Lawler SP (1996) Persistence of an extinction-prone predator-prey interaction through metapopulation dynamics. Ecology 77:1867-1879. doi:10.2307/2265790

Hortas F (2012a) Cigueñuela (Himantopus himantopus). In: SEO/ BirdLife (ed) Atlas de las aves en invierno en España 2007-2010. Ministerio de Agricultura, Alimentación y Medio Ambiente-SEO/BirdLife, Madrid, pp 222-223 (in Spanish)

Hortas F (2012b) Acoveta común (Recurvirostra avosetta). In: SEO/BirdLife (ed) Atlas de las aves en invierno en España 2007-2010. Ministerio de Agricultura, Alimentación y Medio Ambiente-SEO/BirdLife, Madrid, pp 224-225 (in Spanish)

Hortas F, Amat JA, Figuerola J (2012) Chorlitejo Patinegro (Charadrius alexandrinus). In: SEO/BirdLife (ed) Atlas de las aves en invierno en España 2007-2010. Ministerio de Agricultura, Alimentación y Medio Ambiente-SEO/BirdLife, Madrid, pp 234-235 (in Spanish)

Hötker H (2002) Arrival of Pied Avocets Recurvirostra avosetta at the breeding site: effects of winter quarters and consequences for reproductive success. Ardea 90:379-387

Ims RA, Steen H (1990) Geographical synchrony in microtine population cycles: a theoretical evaluation of the role of nomadic predators. Oikos 57:381-387. doi:10.2307/3565968

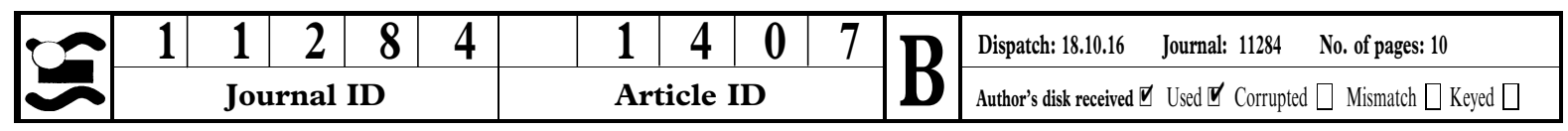


Ives AR, Klopfer ED (1997) Spatial variation in abundance created by stochastic temporal variation. Ecology 78:1907-1913. doi:10.1890/0012-9658(1997)078[1907:SVIACB]2.0.CO;2

Koenig WD (1998) Spatial autocorrelation in California land birds. Conserv Biol 12:612-620. doi:10.1111/j.1523-1739.1998.97034.x

Koenig WD (2001) Spatial autocorrelation and local disappearances in wintering North American birds. Ecology 82:2636-2644. doi:10.1890/0012-9658(2001)082[2636: SAALDI]2.0.CO;2

Koenig WD (2002) Global patterns of environmental synchrony and the Moran effect. Ecography 25:283-288. doi:10.1034/j. 1600-0587.2002.250304.x

Kosztolányi A, Székely T, Cuthill IC, Yılmaz KT, Berberoğlu S (2006) Ecological constraints on breeding system evolution: the influence of habitat on brood desertion in Kentish Plover. J Anim Ecol 75:257-265. doi:10.1111/j.1365-2656.2006.01049.x

Kosztolányi A, Székely T, Cuthill IC (2007) The function of habitat change during brood-rearing in the precocial Kentish plover Charadrius alexandrinus. Acta Ethol 10:73-79. doi:10.1007/s10 211-007-0032-z

Kuwae T (2007) Diurnal and nocturnal feeding rate in Kentish plovers Charadrius alexandrinus on an intertidal flat as recorded by telescopic video systems. Mar Biol 151:663-673. doi: 10.1007/s00227-006-0506-y

Kvasnes MAJ, Storaas T, Pedersen HC, Bjørk S, Nilsen EB (2013) Spatial dynamics of Norwegian tetraonid populations. Ecol Res 25:367-374. doi:10.1007/s11284-009-0665-7

Liebhold A, Koenig WD, Bjørnstad ON (2004) Spatial synchrony in population dynamics. Ann Rev Ecol Evol Syst 35:467-490. doi:10.1146/annurev.ecolsys.34.011802.132516

Liu Z, Gao M, Li Z, Liu H (2009) Dispersal, colored environmental noise, and spatial synchrony in population dynamics: analyzing a discrete host-parasitoid population model. Ecol Res 24:383-392. doi:10.1007/s11284-008-0513-1

Martinez-Santos P, De Stefano L, Llamas MR, Martínez-Alfaro PE (2008) Wetland restoration in the Mancha Occidental aquifer, Spain: a critical perspective on water, agricultural, and environmental policies. Restor Ecol 16:511-521. doi 10.1111/j.1526-100X.2008.00410.x

Moran PAP (1953) The statistical analysis of the Canadian lynx cycle. Aust J Zool 1:291-298. doi:10.1071/ZO9530291

Mortelliti A, Westgate M, Stein J, Wood J, Lindenmayer DB (2015) Ecological and spatial drivers of population synchrony in bird assemblages. Basic Appl Ecol 16:269-278. doi: 10.1016/j.baae.2015.01.008

Ntiamoa-Baidu Y, Piersma T, Wiersma P, Poot M, Battley P, Gordon C (1998) Water depth selection, daily feeding routines and diets of waterbirds in coastal lagoons in Ghana. Ibis 140:89-103. doi:10.1111/j.1474-919X.1998.tb04545.x

Paradis E, Baillie SR, Sutherland WJ, Gregory RD (1999) Dispersal and spatial scale affect synchrony in spatial population dynamics. Ecol Lett 2:114-120. doi:10.1046/j.1461-0248.1999. 22060.x

Post E, Forchhammer MC (2002) Synchronization of animal population dynamics by large-scale climate. Nature 420:168171. doi:10.1038/nature01064
Powney GD, Roy DB, Chapman D, Brereton T, Oliver TH (2011) Measuring functional connectivity using long-term monitoring data. Methods Ecol Evol 2:527-533. doi:10.1111/j.2041-210X. 2011.00098.x

R Development Core Team (2014) R: a language and environment for statistical computing. R Foundation for Statistical Computing, Vienna

Ranta E, Kaitala V, Lindstrom J, Linden H (1995) Synchrony in population dynamics. Proc R Soc B Biol Sci 262:113-118. doi: 10.1098/rspb.1995.0184

Ranta E, Kaitala V, Lindstrom J (1999) Spatially autocorrelated disturbances and patterns in population synchrony. Proc R Soc B Biol Sci 266:1851-1856. doi:10.1098/rspb.1999.0856

Roshier DA, Robertson AI, Kingsford RT (2002) Responses of waterbirds to flooding in an arid region of Australia and implications for conservation. Biol Conserv 106:399-411. doi: 10.1016/S0006-3207(01)00268-3

Ruetz CR III, Trexler JC, Jordan F, Loftus WF, Perry SA (2005) Population dynamics of wetland fishes: spatio-temporal patterns synchronized by hydrological disturbance? J Anim Ecol 74:322-332. doi:10.1111/j.1365-2656.2005.00926.x

SEO/BirdLife (2016a) Himantopus himantopus. Distribución de aves anilladas en España recuperadas por país. http://www. anillamientoseo.org/. Accessed 08 Sep 2016 (in Spanish)

SEO/BirdLife (2016b) Charadrius alexandrinus. Distribución de aves anilladas en España recuperadas por país. http://www. anillamientoseo.org/. Accessed 08 Sep 2016 (in Spanish)

Sirot E, Touzalin F (2014) Temporal patterns of arrival from migration as a response to competition for breeding space. J Avian Biol 45:109-112. doi:10.1111/j.1600-048X.2013.00184.X

Sutcliffe LO, Thomas CD, Moss D (1996) Spatial synchrony and asynchrony in butterfly population dynamics. J Anim Ecol 65:85-95. doi: $10.2307 / 5702$

Thioulouse J, Chessel D, Dolédec S, Olivier JM (1997) ADE-4: a multivariate analysis and graphical display software. Stat Comput 7:75-83. doi:10.1023/A:1018513530268

Thrall PH, Burdon JJ, Bock CH (2001) Short-term epidemic dynamics in the Cakile maritima-Alternaria brassicicola hostpathogen association. J Ecol 89:723-735. doi:10.1046/j.00220477.2001.00598.x

Trenham PC, Koenig WD, Mossman MJ, Stark SL (2003) Regional dynamics of wetland-breeding frogs and toads: turnover and synchrony. Ecol Appl 13:1522-1532. doi:10.1890/02-5206

Vidal D, Anza I, Taggart MA, Ramírez-Pérez E, Crespo E, Hofle U, Mateo R (2013) Environmental factors influencing the prevalence of a Clostridium botulinum type $\mathrm{C} / \mathrm{D}$ mosaic strain in nonpermanent Mediterranean wetlands. Appl Environ Microbiol 80:4264-4271. doi:10.1128/AEM.01191-13

Williams CK, Ives AR, Applegate RD (2003) Population dynamics across geographical ranges: time-series analyses of three small game species. Ecology 84:2654-2667. doi:10.1890/03-0038

Zar JH (2010) Biostatistical analysis, 5th edn. Prentice-Hall, Englewood Cliffs

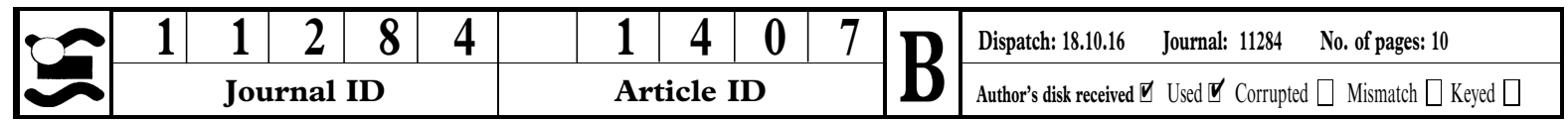

